\title{
The quality of life of farmers with chronic obstructive pulmonary disease (COPD)
}

\author{
Joanna Milanowska', Barbara Mackiewicz², Paweł Węgorowski ${ }^{3}$, Janusz Milanowski², \\ Piotr Milanowski ${ }^{4}$, Marta Makara-Studzińska ${ }^{5}$ \\ ${ }^{1}$ Department of Applied Psychology, Medical University of Lublin, Poland \\ ${ }^{2}$ Chair and Department of Pneumology, Oncology and Allergology, Medical University of Lublin, Poland \\ ${ }^{3}$ Department of Oncology, Medical University of Lublin, Poland \\ ${ }^{4}$ Department of Diagnostic and Minisurgery of Glaucoma, Mesical University of Lublin, Poland \\ ${ }^{5}$ Department of Health Psychology, Jagiellonian University Medical College, Cracow, Poland
}

Milanowska J, Mackiewicz B, Węgorowski P, Milanowski J, Milanowski P, Makara-Studzińska M. The quality of life of farmers with chronic obstructive pulmonary disease (COPD). Ann Agric Environ Med. 2017; 24(2): 283-287. https://doi.org/10.26444/aaem/74651

\begin{abstract}
Introduction and objective. COPD is a medical state characterized by chronically poor airflow, and typically worsens over time. Farmers have an increased risk of COPD because of being exposed to ammonia, hydrogen sulfide, inorganic dust, and organic dust. The quality of life of the ill depends on biomedical as well as psychosocial factors, the impact of which has not been a frequent subject of studies among COPD patients. The aim of the study was to indicate the factors that have negative and positive influence on the quality of life of farmers suffering from COPD.

Materials and method. The study was conducted among 84 farmers treated for COPD in the Department of Pneumology, Oncology and Allergology of the Medical University in Lublin, Poland. The differences between the farmers concerned: severity of the disease, level of education and income, frequency of smoking tobacco and drinking alcohol, kinds of support they receive from their families, and the level of depression and anxiety experienced by the patients.

Results. The study revealed that most patients suffered from depressive and anxiety disorders, and the level of depression higher among the patients who smoked more. Lack of family support had significant influence on exacerbation of the patient's depressive and anxiety symptoms. Patients who had recently experienced a critical situation presented with more severe COPD symptoms, lower quality of life and a higher level of depression. Higher income of the patients had positive influence on their quality of life. Farmers addicted to alcohol suffered from a higher level of anxiety.
\end{abstract}

\section{Key words}

Chronic Obstructive Pulmonary Disease (COPD), Life Quality, emotional and behavioural difficulties, farmers

\section{INTRODUCTION}

Chronic Obstructive Pulmonary Disease (COPD) is nowadays one of the most serious problems of public health, both in Poland and worldwide, with both also as the reasons for morbidity and mortality [1]. It is estimated that in Poland $8-10 \%$ of men and $3-5 \%$ of women suffer from COPD, and it is the fourth cause of deaths [2]. Worldwide, 210 million people suffer from it, and it is estimated that by 2020 it will have become the third cause of deaths [3]. For the above reasons, the amount of research on pathogenesis [4], diagnostics, prevention and methods of treatment have risen sharply during the last 10 years.

Farmers have an increased risk of chronic bronchitis, COPD, and reduced $\mathrm{FEV}_{1}$. Ammonia, hydrogen sulfide, inorganic dust, and organic dust may be causally involved, and a role for specific biological agents cannot be excluded [5].

The most important factors when dealing with patients suffering from COPD are: early diagnosis, widely understood prevention, pharmacological treatment when revealed by clinical symptoms, and rehabilitation $[6,7]$.

For many years, the dynamic development of research on the quality of life from the medical aspect has been observed. The biggest number of reports concern chronic diseases [8],

Address for correspondence: Joanna Milanowska, Department of Applied Psychology, Medical University in Lublin

E-mail: jmilanowska@yahoo.com

Received: 7 October 2016; accepted: 6 February 2017; first published on May 2017 one of which is COPD. The chronic and progressive character of the disease, and frequent exacerbation characteristic for COPD, do not only have a negative influence on prognosis, but also are the reason for deterioration of the quality of life of the patients $[2,9]$.

The Polish Society of Lung Diseases, in their recommendations concerning diagnosis and treatment of chronic obstructive pulmonary disease, point out the basic aims of treating COPD, which is: reducing its progress, reducing symptoms that influence the deterioration of the quality of life, prevention and treatment of exacerbations of the disease and its complications [10]. This proves that it is important to study the quality of life when estimating the effectiveness of treating COPD.

In the research, factors influencing the quality of life of people suffering from COPD, both in a positive and negative way, have been estimated and analyzed. The factors are as follows: severity of the disease, co-existing mental disorders, smoking, performing sports, level of income, level of education, support of family and friends, and whether in the past year the patient had experienced a critical situation unconnected with the disease.

In order to compare the results with the latest research achievements in this area, the authors reviewed the literature on the quality of life in relation to chronic obstructive pulmonary disease in such databases as: Pubmed and Polish Medical Bibliography. 


\section{OBJECTIVES}

The aim of the study was to indicate the factors that have negative and positive influences on the quality of life of farmers suffering from COPD. Factors that were analyzed included: severity of the disease, co-existing emotional problems, smoking tobacco, active lifestyle, level of income, level of education, support of family and friends, and whether in the past year the patient had experienced a critical situation unconnected with the disease

\section{MATERIALS AND METHOD}

The research was performed among 84 farmers suffering from COPD without serious co-existing diseases from the Lublin Province in southeast, who were patients of the Department of Pneumonology, Oncology and Allergology at Medical University in Lublin. The group who participated in the study consisted of 67 men (79.8\% of the group) and 17 women (20.2\% of the group); mean age $65.06(\mathrm{SD}=9.2)$. The youngest patient was aged 40 , the oldest -85 . Disease severity ranged from light to very serious, which was defined after a spirometry test of each patients The biggest number of patients -35 , were qualified as severe ( $42 \%$ of the group), 31 patients had a moderate state of the illness $(37 \%$ of the group), 10 had very severe COPD (12\% of the group) and 8 patients had symptoms of the mild form of the disease $(9 \%$ of the group). The differences between the patients concerned: the level of education and income, frequency of smoking and drinking alcohol, support received from families, and having or not having experienced a critical situation in their life in the past year. These data were collected among the patients by a questionnaire designed by the authors (Appendix 1).

To estimate the quality of life of the patients with the recognized disease, two kinds of questionnaires were used: general and disease-specific measures [11]. General questionnaires allow estimation of the quality of life, entirely depending on the influence of the disease or the process of the treatment, whereas disease-specific measures allow estimations which include the specifics of a particular patient. An example of the first is the Nottingham Health Profile Short Form 36 (SF-36) which can also be used for the healthy. One of the most frequent methods used for people suffering from COPD is the St George's Respiratory Questionnaire (SGRQ). Both types of questionnaires were used in the presented study.

SF-36, which is a standard tool, allows the estimation of overall health, and is used both for the healthy and the ill. It consists of 11 questions, containing 36 statements. The results are later converted according to particular rules, and represented on a $0-100$ - points scale (where 0 stands for the most severe condition of quality of life) [12].

The SGRQ questionnaire was created to measure the quality of life connected with the health of patients suffering from asthma and chronic lung disease. The scale estimates 3 areas of functioning of the patients: the sphere of symptoms, activity, and influence of the disease on the patient's life [13]. The symptoms sphere estimates the influence of symptoms originating from respiratory system of the patient, their frequency and severity. The activity sphere concerns areas connected with the influence of physical activity which exacerbate the symptoms of the disease, and connected with the influence of shortness of breath on the physical activity of the patient. The sphere of influence includes a wide spectrum of aspects connected with the social functioning of the patient, and also estimates the presence of psychological dysfunctions caused by the lung disease. The final result is also calculated which presents the influence of the disease on the general health status. The results are presented in percentage, where 100 stands for the worst possible health status, whereas 0 - the best state of health.

Other factors that were also estimated included: the level of depression (estimated by The Beck Depression Inventory), and the level of anxiety experienced by patients (estimated by State-Trait Anxiety Inventory).

Statistical analysis was performed using Statistica software for Windows. The tests used to analyse the data were: ANOVA and post-hoc tests (Sheffe's method) to analyze the significance of differences between the groups, Student's $t$ test and Pearson's correlation test.

\section{RESULTS}

$8(9.5 \%)$ of the respondents declare themselves to be nonsmokers, $27(32 \%)$ of the patients still smoke cigarettes, and $49(58.5 \%)$ had given up smoking. A moderate positive correlation $(\mathrm{r}=0.370 ; \mathrm{p}=0.01)$ between depressive disorders and the number of cigarettes smoked by patients was observed. There was also moderate correlation $(\mathrm{r}=0.325$; $\mathrm{p}=0.05$ ) between the number of years-and-packs and the higher level of depressive disorders.

The results showed that most patients suffered from emotional disorders. More than a half - 46 (55\%) - of the patients showED symptoms of moderate depression, 9 (11) of them of severe depression, and only 29 (34\%) Did not show symptoms of depressive disorders.

A high level of anxiety characterised 16 (19\%) of the respondents, and a moderete level 61 (73\%) of them. Only 7 (8\%) patients were characterised by a low level of anxiety.

$12(14.3 \%)$ patients admitted to have problems connected to alcohol usage, 72 (85.7\%) others did not claim such problems. The results showed that those with an alcohol problem suffered from a higher level of currently experienced anxiety than the patients who did not have alcoholic problems $(\mathrm{t}=-$ 2.329; $\mathrm{p}=0.024)$.

49 (58\%) patients described their family as being unsupportive, while 35 (42\%) found their family supportive and caring. A substantial influence of the lack of patient's family support on exacerbation of the patient's depressive and anxiety symptoms were observed. The patients who could rely on family support had a substantially lower lever of anxiety, both as a feature $(\mathrm{t}=3.148 ; \mathrm{p}=0.003)$ and a current state $(\mathrm{t}=2.004 ; \mathrm{p}=0.05)$. They also presented a much lower level of depression $(\mathrm{t}=3.451 ; \mathrm{p}=0.001)$.

There were 19 (22.6\%) patients, who declared experiencing a difficult life event during the last year, whereas $65(77.4 \%)$ did not recall such a situation. The study showed that the patients who had recently experienced a critical situation in the past year (e.g. the death of a close person) presented worse health symptoms connected with COPD $(\mathrm{t}=-2.268 ; \mathrm{p}=0.029)$, a lower quality of life $(\mathrm{t}=2.445 ; \mathrm{p}=0.018)$ and a higher level of depression $(\mathrm{t}=-3.341 ; \mathrm{p}=0.002)$.

More than half of the patients - $48(57 \%)$ declared their income to be higher than 1,000 PLN, 36 (43\%) of them were 
characterized by a lower income. The research confirmed a positive influence of higher income of the patients on their quality of life. It was proved that those patients whose income exceeds 1,000 PLN per person in household have on average 10 points higher quality of life than those whose income is lower than 1,000 PLN $(\mathrm{t}=2.096, \mathrm{p}=0.041)$.

Most of the responded farmers - 63 (75\%) - had never performed any sport, 21 (25\%) declared they had performed some kind of sport in their lives. The study proved that those patients who had performed sports regularly in the past showed a positive influence on their quality of lives, and had much a higher level of the quality of life than those whose lives had been less active. This was confirmed both by results taken from SF-36 $(\mathrm{t}=-2.770 ; \mathrm{p}=0.008)$ and from the St George's Respiratory Questionnaire ( $\mathrm{t}=2.096$; $\mathrm{p}=0.042)$.

\section{DISCUSSION}

Numerous studies conducted worldwide confirm the fact that shortness of breath and reduced exercise capacity $[14,15,16$, $17,18,19,20,21]$ are among the symptoms that substantially reduce the quality of life of the ill. Moreover, the level of disease severity leads to a poorer quality of life $[22,23,24]$. The presented study confirms this dependency.

According to some researchers, the duration of smoking cigarettes by patients suffering from COPD, expressed in years-and-packets, seems to be an essential factor determining the decrease in the level of the quality of life $[14,17]$. Others studies have shown a connection between the fact of giving up smoking and the improvement of the quality of life [25]. Results of the latest research, however, do not confirm this relationship.

The presented study determining this problem, however a positive correlation between the exacerbation of psychological disorders and the number of cigarettes smoked per day. This correlation can be explained by the fact that patients nowadays are aware of the negative influence of smoking on their health, but are nevertheless not able to give it up, which results in regular depressive moods. Smoking itself also affects exacerbation of the negative symptoms of COPD, such as shortness of breath, or the frequency of exacerbation co-existing with COPD, which indirectly influences the decrease of mood among smokers. The opposite hypothesis is also taken into consideration, that decrease in mood resulting from the disease affects the increase in the number of cigarettes smoked daily.

Although research on relationship between smoking and depression is not unequivocal, it is evident that smoking does affect COPD in a negative way; giving up smoking should therefore be a priority. Medical staff contacting patients should motivate them to give up smoking and to present them with various ways of dealing with the craving (including increasingly effective pharmacologic methods).

In the current study, the existence of other addictions was also investigated -7 patients declared being addicted to alcohol. Despite the small group, it was definitely noted that the level of anxiety was much higher with the addicted than with those who did not have alcoholic problems. It is, nevertheless, another factor that increases the psychological discomfort among those who suffer regardless. It is worthwhile expanding the research group of the patients suffering from COPD who are also addicted to alcohol, and determine whether they are covered with additional help, or whether they receive basic psycho-education connected with the co-existing disease. It would also be worth researching the influence of active alcohol addiction on the duration of nicotine addiction.

Chronic obstructive pulmonary disease is often accompanied by anxiety disorders and those connected with changes of mood $[26,27]$. These co-existing psychological and psychiatric problems, among which depression and anxiety are the most common, often play a crucial role in the clinic picture of COPD. Although it is of little account whether they influence the treatment of COPD, they definitely affect the exacerbation of the quality of life to a high degree $[28,29]$.

The results of the research held in the Department of Pneumology, Oncology and Allergology of Medical University in Lublin showed that $66 \%$ of the farmers treated because of chronic obstructive pulmonary disease also suffered from depressive disorders. Furthermore, every $10^{\text {th }}$ patient presented symptoms of severe depression, which demanded specialist treatment.

The majority of the researched presented an increased level of anxiety, with only $13 \%$ of the patients presented a low level of anxiety.

The opinions of other researchers concerning the spread of mood and anxiety disorder among patients suffering from COPD are not unequivocal. American studies by Julian et al. [30] estimate that about $25-30 \%$ of the ill suffer from mood disorders, whereas British researchers, Yohannes et al. [31], claim that this percentage increases even up to 60\%. Recent Polish research conducted in 2015 in Krakow, shows that $44 \%$ of the patients with severe COPD suffered from anxiety panic, and $40 \%$ of them revealed depression. Patients with depressive symptoms also showed deeper anxiety symptoms [32].

Such factors as: the level of shortness of breath experienced by patients [33], inflammation co-existing with the disease [34], living in chronic, acute stress, oxidative stress and genetic susceptibilities [35] are mentioned as pathogenic factors of mental disorders in COPD. Polish research by Potoczek et al. [36] have shown that women with severe COPD suffer from more frequent depressive and anxiety symptoms than men at the same level of severity of the disease. The authors explain these differences as a result of women's different social roles, their specifics, and the fact that adult women suffer from mental disorders more frequently than men. Research performed at the Lublin Clinic, however, does not conform with this. In the opinion of the authors of the current study, previous results could have meant that men more rarely admitted to anxiety because of social approval. In the current study, it was attempted to exclude this factor by conducting a deep psychological interview before completion of the questionnaire, which aimed at preparing the patients for participation in the study by acquiring trust between the patient and the researcher. This factor should be analyzed more deeply on a larger group of women than that presented here.

Current research also shows that the lack of family support appeared to be another essential factor for the pathogenesis of depressive disorders among patients suffering from COPD. Patients who received such support presented a much lower level of depression than those whose families reacted with anxiety, excessive care, anger or indifference. This fact should be another point to be included in the psycho-education of 
the patients' families for proper dealing with the disease. It would be desirable for the patients who do not receive family support to be included in additional psychological care.

It is a worrisome fact that despite such a high severity of psychological disorders among patients suffering from COPD, and although their essential influence on the quality of life has been proved, this area seems to have been neglected for many years; firstly, because only a few patients are examined for this problem, and secondly, because even those patients who have been diagnosed psychiatrically in a reliable way are hardly ever under psychological or specialist pharmacological treatment [37]. Interviews with the patients conducted in the presented study, unfortunately confirmed this fact. Undoubtedly, an optimal solution for patients suffering from COPD would be for them to have the possibility of an honest and open talk with a fully empathetic person who understands the specifics of the disease. A conversation with an experienced physician could also be helpful for such individuals, unfortunately it has been observed that only a few doctors are willing to have such a talk with their patients, the probable reasons being lack of time, lack of active communication abilities, or fear. The gap could be filled by giving the patients a wider scope of professional psychological help. However, in many places, there are financial reasons that limit the scope, although in some other cases the medical staff are unaware of this need and its importance. Creating support groups could be a possible solution; such groups would consist of patients who assist one another by empathic listening to the problems of others, sharing similar experiences and knowledge about the disease. Such a group could be supported by a professional, a doctor educated in psychology, a clinic psychologist, or adequately prepared volunteers. Families of patients who are also exposed to depressive and anxiety disorders could also make use of such assistance.

It would be worth researching the use of other methods commonly used by people who suffer from a higher level of anxiety, such as various forms of relaxation or music therapy.

As for other chronically ill people, there are tests on the influence of socio- and economic status on the quality of life of patients with chronic obstructive pulmonary disease. Some studies prove the existence of this influence $[14,38,39]$, whereas others do not confirm it [40,41]. The Polish authors, Bąk et al. [42], have recently shown that there is an influence on the quality of life of such factors as: education, monthly income, employment status and profession. According to these authors, those with a lower level of education presented a lower level of the quality of life, especially from the aspect of physical functioning. Similar results can be found in earlier Spanish studies conducted by Garrido et al. [38], or in American research by Mody et al. [43]. The results of the above studies also proved the influence of material status on the quality of life. People with a higher income presented a higher level of the quality of life, especially from such aspects as activity and mental and social functioning. The studies by Orbon et al. [44] revealed that white-collar workers presented a much higher quality of life compared to manual workers, and that people still working presented a higher level of quality of life than pensioners and the retired, when considering the similar severity of the disease. It is worth mentioning that other research did not reveal any essential influence of the profession on the quality of life $[45,46]$.
Current research confirmed the positive influence of higher income on a better quality of life. However, no correlation between education or profession and the quality of life of the ill was revealed. These problems enquire further research on a bigger research group.

From the statistical analysis, it appears that in the situation where a patient had experienced a crisis in the last year, this influenced a decrease in the quality of life to a high degree. What is more, such experiences also reflected a higher level of depression and a worsening of COPD symptoms.

The review study of the above-described lung disease showed that this factor had not been taken into consideration in earlier studies concerning the quality of life, and should be an inspiration to conduct further research in this area.

In the presented study it was noticed that patients who had performed in sport in the past presented a higher level of the quality of life connected with health (measured in SF-36), and a higher quality of life connected with active the sphere (St George's Respiratory Questionnaire). Taking into account this aspect of the pathogenesis of COPD, these patients are in a better situation than those people who had led a less active life.

\section{CONCLUSIONS}

As a result of the research, the following factors that have a negative influence on the quality of life of farmers suffering from chronic obstructive pulmonary disease have been revealed: the severity of the disease, depressive and anxiety disorders, experience of a critical situation in the past year, lack of family support, sedentary lifestyle in the period preceding the disease, and low income. Although those who take care of the patients do not have any influence on some of these factors, they do have an impact on some, e.g. emotional problems, even to the point of eliminating them. Motivating and encouraging patients to lead a more healthy way of life, including physical activeness, giving up smoking and reducing alcohol drinking, could provide the patients with a better chance for a higher quality of life, and could prevent the appearance of emotional disorders.

Widely understood communication with the patient and its influence on the quality of life seems to be an interesting subject for further scientific research.

\section{REFERENCES}

1. Stelmach A, Wanot B, Biskupek-Wanot A. Chromic Obstructive Pulmonary disease (COPD) - an underestimated problem. PNAP. 2016; 17(2): 69-79.

2. Pauwels RA, Buist AS, Ma P. Global strategy for the diagnosis, management, and prevention of chronic obstructive pulmonary disease: National Heart, Lung, and Blood Institute and World Health Organization Global Initiative for Chronic Obstructive Lung Disease (GOLD): executive summary. Respir Care. 2001; 46: 798-825.

3. Lopez AD, Shibuya K, Rao C et.al. Chronic obsturative pulmonary disease: current burden and future projection. Eur Respir J. 2006; 27: 397-412.

4. Semik-Orzech A, Pierzchała W. Mechanizmy molekularne zapalenia w przewlekłej obturacyjnej chorobie płuc. Pneumonol Alergol Pol. 2009; 77: 66-71.

5. Eduard W, Pearce N, Douwes J. Chronic Bronchitis, COPD, and Lung Function in Farmers: The Role of Biological Agents. Chest. 2009; 136(3): 716-725. 
6. Cynowska B, Słomiński JM. Przewlekła obturacyjna choroba płuc (POChP) w codziennej praktyce lekarskiej. Family Med Prim Care Rev. 2007; 9(3): 715-720.

7. Jelusic D, Wittmann, M, Schuler M, Schultz K. How does regular exercise affect dyspnoe (TDI) and quality of life (CAT) of COPDpatients 1 year after an inpatient pulmonary rehabilitation (PR)? Eur Respir J. 2015; 46(59): 553.

8. Kulczycka L, Sysa-Jędrzejowska A, Robak E. Jakość życia chorych na układowy toczeń rumieniowaty ze szczególnym uwzględnieniem metodyki badań. Postepy Hig Med Dosw. 2007; 61: 472-477.

9. Voelker H, Nayeemuddin, M, Albert RK, Connett JE, Bailey WC, Casaburi R., Han MK. Short-Term Impact Of Frequency Of COPD Exacerbations On Quality Of Life. Critical Care 2015; 6: 7.

10. Śliwiński P, Górecka D, Jassem E, Pierzchała W. Zalecenia Polskiego Towarzystwa Chorób Płuc dotyczącerozpoznawania i leczenia przewlekłej obturacyjnej choroby płuc. Pneumon Alergol Pol. 2014; 82(3), 227-263.

11. Guyatt GH, Feeny DH, Patrick DL. Measuring health-related quality of life. Ann Intern Med. 1993; 118: 622-629.

12. Ware JE, Kosinski M, Keller SD. SF-36 physical and mental component summary measures - a user's manual. The Health Institute, Boston 1994.

13. Jones P, Qiirk F, Baveystock CA. A selfcomplete measure of health status for chronic airflow limitation: The St. George's Respiratory Questionnaire. A Rev Resp Dis. 1992; 145: 1321-7.

14. Hesselink A, van der Windt DA, Penninx BW. What predict change in pulmonary function and quality of life in asthma or COPD? J Asthma. 2006; 43(7): 513-19.

15. Martin A, Rodriguez- Gonzalez Moro JM, Izquierdo, Gobartt E, de Lukas P. Health-related quality of life in outpatients with COPD in daily practice: the VICE Spanish study, Int J Chron Obstruct Pulmon Dis. 2008; 3(4): 683-92.

16. Blinderman C, Homel P, Billings JA, Tennstedt S, Portenoy RK. Symptom distress and quality of life in patients with advanced chronic pulmonary disease. J Pain Symptom Manage. 2009; 38(1): 115-23.

17. Hajiro T, Nishimura K, Tsukino M, Ikeda A, Oga T, Izumi T. A comparison of the level of dyspnea vs disease severity in indicating the health-related quality of life of patients with COPD. Chest. 1999; 116(6): 1632-7

18. Haave E, Hyland ME, Skumlien S. The relation between measures of health status and quality of life in COPD. Chron Respir Dis. 2006; 3(4): 195-9.

19. Jones PW, Quirk FH, Baveystock CM, Littlejohns P. A self-complete measure of health status for chronic airflow limitation. The Saint George's Respiratory Questionnaire. Am Rev Respir Dis. 1992; 145(6): 1321-7.

20. Engstorm C, Persson L, Larsson S, Sullivan M. Health-related quality of life in COPD: why both disease-specific and generic measures should be use. Eur Respir J. 2001; 18(1): 69-76.

21. de La Fuente CR, de La Iglesia MF, Ramos PV, Pellicer VC, Nicolás MR, Diz-Lois M F. Factor analysis of the health related quality of life of patients with stable chronic obstructive pulmonary disease. Arch Bronconeumol. 2001; 37(10): 411-6.

22. Punekar YS, Rodriguez-Roisin R, Sculpher M, Jones P, Spencer M. Implications of chronic obstructive pulmonary disease (COPD) on patients' health status: a western view. Respir Mes. 2007; 101(3): 661-9.

23. Wijnhoven HA, Kriegsman DM, Hesselink AE, Penninx BW, de Haan M. Determinants of different dimensions of disease severity in asthma and Copd: pulmonary function and health-related quality of life. Chest. 2001; 119(4): 1034-42.

24. Ong KC, Lu SJ, Soh CS. Does the multidimentional grading system (BODE) correspond to differences in health status of patients with COPD? Int J Chron Obstruct Pulmon Dis. 2006; 1(1): 91-6.

25. Prigatano GP, Wright EC, Levin D. Quality of life and its predictors in patients with mild hypoxemia and chronic obstructive pulmonary disease. Arch Intern Med. 1984; 144: 1613-9.

26. Pietras T, Witusik A, Panek M, Hołub M, Gałecki P, Wujcik R, Górski P. Lęk i depresja u chorych na choroby obturacyjne płuc. Pol Merkur Lek. 2009; 26: 631-635.
27. Schneider C, Jick SS, Bothner U, Meier CR. COPD and the risk of depression. Chest. 2010; 137: 341-347.

28. Potoczek A, Niżankowska-Mogilnicka E, Bochenek G, Szczeklik A. Związki pomiędzy zespołem lęku napadowego i depresją a mechanizmami obronnymi, koherencją i funkcjonowaniem rodzinnym u pacjentów z rozpoznaniem ciężkiej POCHP. Psychiatr Pol. 2008; 42(5): 731-748.

29. Gardener AC, Farquhar M, Butcher HH, Moore C, Ewing G, White P, Mendonca $S$. Higher service use amongst the patients with advanced COPD and psychological co-morbidities: Associations with quality of life, co-morbidities and exacerbations. Thorax. 2015; (70): 100-101.

30. Julian LJ, Gregorich SE, Earnest G, Eisner MD, Chen H, Blanc, PD, Katz PP. Screening for depression in chronic obstructive pulmonary disease. COPD. 2009; 6: 452-8.

31. Yohannes A, Baldwin R, Connoly M. Depression and anxiety in eldery patients with chronic obstructive pulmonary disease. Age Agening. 2006; 35: 457-459.

32. PRAC, RO, CZASOPISMA, LR. Związki pomiędzy zespołem lęku napadowego i depresja a mechanizmami obronnymi, koherencją i funkcjonowaniem rodzinnym pacjentów z rozpoznaniem ciężkiej POCHP. Psychiatria i Psychoterapia. 2015; 11(4): 731-748.

33. Talarowska M, Florkowski A, Gałecki P, Szemraj J, Zboralski, K, Pietras T, Górski P. The impact of psychological variables on the presentation and progress of asthma and patient's cognitive functions. Pneumon Alergol Pol. 2009; 77(6): 554-559.

34. Pace TW, Miller AH. Cytokines and glucocorticoid receptor signaling. Revelance to major depression. AnNY Acad Sci. 2009; 1179: 86-105.

35. Pietras T, Witusik A, Panek M, Gałecki P, Szemraj J, Górski P. Lęk i depresja a polimorfizm genu kodującego dysmutazę ponadtlenkowa u chorych na przewlekłą obturacyjną chorobę płuc. Pol Merk Lek. 2010; 29 (171): 165.

36. Potoczek A, Niżankowska-Moglnicka E, Bochenek G, Szczeklik A. Ciężka POCHP i płeć chorych a obecność doznanych urazów psychicznych. Psychiatr Pol. 2008; 5: 719-730.

37. Kunik ME, Roundy K, Veazey C, Souchek J, Richardson P, Wray N, Stanley M. Surprisingly high prevalence of anxiety and depression in chronic breathing disorders. Chest. 2005; 127: 1205-1211.

38. Garrido PC, de Miguel Diez J, Gutierrez JR, Centeno AM, Vázquez EG, de Miguel ÁG, García RJ. Negative impact of chronic obstructive pulmonary disease on the health - related quality of life of patients. Results of the EPIDEPOC study, Health Qual Life Outcomes. 2006; 23: 4-31.

39. de La Fuente CR, de La Iglesia MF, Ramos PV, Pellicer V C, Nicolás MR, Diz-Lois MF. Factor analysis of the health related quality of life of patients with stable chronic obstructive pulmonary disease. Arch Bronconeumol. 2001; 37: 411-416.

40. Ketelaars CA, Schlosser MA, Mostert R, Huyer Abu-Saad H, Halfens RJ, Wouters EF. Determinants of health-related quality of life in patients with chronic obstructive pulmonary disease. Thorax. 1996; 51: 39-43.

41. Stahl E, Lindberg A, Jansson S, Rönmark E, Svensson K, Andersson F, Lundbäck B. Health related quality of life is related to COPD disease severity. Health Qual Life Outcomes. 2006; 23: 4-31.

42. Bąk-Drabik K, Ziora D. Wpływ statusu socjoekonomicznego na jakość życia chorych na przewlekłą obturacyjna chorobę płuc. Pneumon Alergol Pol. 2010; 78(1): 3-13.

43. Mody R., Smith MJ. Smoking status and health-related quality of life: as findings from the 2001. Am J Health Promot. 2006; 20(4): 251-8.

44. Orbon KH, Schermer TR, van der Gulden JW, Chavannes NH, Akkermans RP, Van Schayck OP, Folgering HT. Employment status and qualityof life in patients with chronic obstructive pulmonary disease. Int Arch Occup Environ Health. 2005; 78(6): 467-74.

45. Ståhl E, Lindberg A, Jansson SA, Rönmark E, Svensson K, Andersson F, Lundbäck B. Health related quality of life is related to COPD disease severity. Health Qual Life Outcomes. 2005; 3(1): 1.

46. Ketelaars CA, Schlosser MA, Mostert R, Huyer Abu-Saad H, Halfens RJ, Wouters EF. Determinants of health-related quality of life in patients with chronic obstructive pulmonary disease. Thorax. 1996; 51: 39-43. 